\title{
Why Not Try The Carrot? A Modest Proposal to Grant Immunity to Lawyers Who Disclose Client Financial Misconduct
}

\author{
David McGowan ${ }^{\dagger}$
}

\section{INTRODUCTION}

If the legal profession is serious about attorney disclosure of client financial misconduct, it must address the costs disclosure creates for lawyers who blow the whistle. Taking costs into account offers a more complete picture of the economic incentives and disincentives faced by lawyers who must decide whether to disclose financial scams. I offer a proposal to address these costs and encourage lawyers to disclose more frequently: states and the federal government should grant immunity from civil, criminal, and administrative liability to the first participant in a financial scam to disclose the scam, whether a lawyer, accountant, another professional, or even the client itself.

The economic analysis underlying this proposal suggests that the recent amendments to Model Rules of Professional Conduct I.6 and 1.13 are more cosmetic changes than significant reforms. ${ }^{1}$ The amended rules allow lawyers to disclose some cases of client financial misconduct to prevent or rectify crimes or frauds. ${ }^{2}$ Disclosure is costly to lawyers, however, and the

Copyright (C) 2004 California Law Review, Inc. California Law Review, Inc. (CLR) is a California nonprofit corporation. CLR and the authors are solely responsible for the content of their publications.

$\dagger \quad$ Professor of Law, University of Minnesota Law School. My thanks to Stephen Bundy, Brad Clary, Roger Crampton, Dan Farber, Eric Goldman, Maury Landsman, Mark Lemley, Brett McDonnell, Miranda McGowan, Richard Painter, Tom Sullivan, Brad Wendel, and Bill Wernz for comments. I am particularly grateful to my friend Christopher Leslie, whose comprehensive work on trust and cartels got me thinking along these lines. Remaining mistakes are my fault.

1. MODEL RULES OF PROF'L CONDUCT R. I.6, I.I3 (2003). In conversation on this subject, Fred Zacharias suggested that some disciplinary authorities might interpret a grant of discretion to disclose to require that discretion be exercised, so that in some cases "may" could mean "must." I am skeptical that such a reading would hold up. Cf. In re Goeber, 703 N.E. 2d 1045 (Ind. 1998) (imposing discipline not for failure to disclose client's intent to kill a witness, who he did kill, but for revealing information about witncss). If there is a risk that "may" could be read as "must," however, then that risk creates an expected cost of nondisclosure in some cases, which would reduce the marginal disclosure incentive of my proposal in those cases.

2. Model Rule 1.6(b)(2) allows lawyers to disclose information regarding client misconduct to 
amendments do nothing to address the costs of disclosure. The amendments are therefore unlikely to change actual practice very much. To the extent lawyers are economically rational, behavior will change only when the benefits of disclosure outweigh the costs.

Part I of this Essay explains why these amendments are unlikely to produce much actual disclosure. Part II outlines my proposal and explains why states and the federal government should experiment with giving lawyers incentives to disclose. Part III describes and responds to the main criticisms of my proposal.

\section{I \\ The Current Disclosure Regime}

In August 2003, after many years of debate, the American Bar Association amended Model Rules of Professional Conduct I.6 and I.13 to allow lawyers to blow the whistle on clients who, in the case of Rule I.6, use a lawyer's services to cause or threaten financial harm to third parties, such as investors, or, in the case of Rule 1.I3, on client constituents whose conduct threatens to harm an existing client. Previously, in 2001, the ABA rejected an identical amendment to Rule 1.6. However, two subsequent events created irresistible pressure for reform. First, corporate scandals, including the collapse of Enron, angered the public and created political pressure to crack down on corporate misconduct. In that political climate, the ABA's rejection of the amendment made it seem out of touch with

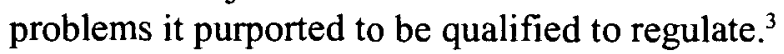

the extent necessary to "prevent the client from committing a crime or fraud that is reasonably certain to result in substantial injury to the financial interests or property of another and in furtherance of which the client has used or is using the lawyer's services." MODEL RULES OF PROF'L CONDUCT R. 1.6. Rule 1.6(b)(3) allows disclosure "to prevent, mitigate or rectify substantial injury to the financial interests or property of another that is reasonably certain to result or has resulted from the client's commission of a crime or fraud in furtherance of which the client has used the lawyer's services." Id. Rule 1.0(d) defines fraud as unlawful conduct with a "purpose to deceive." MODEL RULES OF PROF'L CONDUCT R. 1.0(d). Most cases in which lawyers are accused of enabling client misconduct involve some sort of deceit, so they fit within amended Rule 1.6. See Roger C. Crampton, Enron and the Corporate Lawyer: A Primer on Legal and Ethical Issues, 58 Bus. LAw. 143 (2002) (reciting frauds implicating entity lawyers). There are exceptions, however: some economic misconduct, such as pricefixing and copyright infringement, does not involve deceit. It therefore would be desirable to allow disclosure in any case where client misconduct threatened economic harm, regardless of whether the client deceived anyone. Rule 1.13(b) allows entity counsel to disclose information regarding any "violation of law that reasonably might be imputed to the organization, and that is likely to result in substantial injury to the organization" if the entity's officers and directors do not put a stop to the misconduct. MODEL RULES OF PROF'L CONDUCT R. 1.13(b). In such a case, counsel "may reveal information relating to the representation whether or not Rule 1.6 permits such disclosure, but only if and to the extent the lawyer reasonably believes necessary to prevent substantial injury to the organization." MODEL RULES OF PROF'L CONDUCT R. 1.13(c). Because most significant financial misconduct involves entity clients, the broader wording of Rule 1.13(b) may address misconduct that does not involve deceit.

3. See Thomas D. Morgan \& Ronald D. Rotunda, Model Rules of Professional Conduct and Other Selected Standards 1 (2004) (describing 2003 amendments to Model Rules 
Second, the Securities and Exchange Commission (SEC) proposed rules implementing section 307 of the Sarbanes-Oxley Act. ${ }^{4}$ Section 307 required the SEC to establish minimum standards of conduct for attorneys practicing before the Commission, including rules requiring counsel who learn of unlawful corporate conduct to report such conduct to the firm's chief legal or executive officers, and, if the officers fail to solve the problem, to the firm's directors. This provision did not add much to existing ethical rules, but in November 2002, when the SEC proposed rules complying with section 307 , it included a rule that in some cases would have required counsel to withdraw from representing a firm and notify the SEC of its withdrawal. ${ }^{5}$ That proposed rule was not adopted when the SEC adopted other rules implementing section 307 in January 2003, but the SEC continued to consider it (and still is considering it at the time of this writing). The prospect of SEC action increased pressure on the ABA to take some action of its own. ${ }^{6}$

The 2003 amendments to Model Rules 1.6 and 1.13 are unlikely to change actual practice significantly. Many states already allow lawyers to disclose client misconduct when clients use lawyers to harm others, but disclosure is rare. ${ }^{7}$ More importantly, the amendments do not address the heavy costs of disclosure.

\section{A. The Insufficiency of the Amended Rules}

Consider the following archetypal scenario: a director, officer, or other constituent of an entity client commits a fraud. The constituent decides to lie to investors about the client's revenues, and a lawyer prepares disclosure documents incorporating the client's lies, suspecting they are lies, but not actually writing the lies himself. The lawyer helps close the deal, and then receives information confirming that the documents contained material lies. The lawyer must decide whether to blow the whistle

1.6 and 1.13 and their history); Report of the American Bar Association Task Force on Corporate Responsibility 2 (Mar. 31, 2003), available at http:/www.abanet.org/buslaw/corporateresponsibility/ final_report.pdf [hereinafter ABA Task Force]; Asher Hawkins, In Bid to Fight Corporate Fraud, ABA Amends Two Rules, PA. L. WKLY., Aug. 18, 2003, at 7 (describing the debate). On the scandals and their aftermath, see Susan P. Koniak, Corporate Fraud: See, Lawyers, 26 HARV. J.L. \& PUB. PoL'Y 195 (2003); Susan P. Koniak, When the Hurlyburly's Done: The Bar's Struggle with the SEC, 103 Colum. L. Rev. 1236 (2003).

4. Pub. L. No. 107-204, $§ 307,116$ Stat. 745, 784 (2002).

5. For a description of the rule as proposed and as adopted, see Press Release, Securities and Exchange Commission, SEC Adopts Attorney Conduct Rule Under Sarbanes-Oxley Act (Jan. 23, 2003), http://www.sec.gov/news/press/2003-13.htm.

6. See ABA Task Force, supra note 3, at 6-7.

7. See, e.g., Minn. Rule of Prof'l Conduct R. 1.6(b)(4), State of Minnesota, available at http://www.courts.state.mn.us/lprb/conduct.html (last visited Aug. 30, 2004). For a table summarizing state variations, see MORGAN \& RotUNDA, supra note 3, at 146-49; ABA Task Force, supra note 3, at 44 n.89. 
on the client. What are the costs and benefits of disclosure, and how do they affect a lawyer's decision to disclose client financial misconduct?

Changing the Model Rules to allow lawyers to blow the whistle on client financial misconduct removes one cost of doing so-the risk and expected cost of discipline for breaching confidentiality-but leaves other costs in place. Two types of costs are relevant to a lawyer's decision to disclose: the expected cost of lost fees and the expected cost of litigation. I will address each individually below.

Because disclosure is permissive, lawyers choose whether they will create these other costs. A simple rational actor assumption suggests that lawyers are reluctant to create costs for themselves. The amended rules, therefore, will not increase disclosure much, even in cases where disclosure could stop unlawful conduct or help rectify its consequences.

\section{Disclosure Creates an Expected Cost of Lost Fees}

The expected cost of lost fees refers to the present value of fees a lawyer would lose by disclosing client financial misconduct. If a lawyer blows the whistle on a client's scam, the client will probably fire the lawyer, and the lawyer may lose the fees on that deal. ${ }^{8}$ The lawyer will also incur a cost equal to the present value of future fee income from that client. (The larger and more reliable the fees, the higher this cost is, so the expected cost will be higher for lawyers who represent stable, solvent clients that rely heavily on the lawyer than financially shaky clients or clients who spread their legal business across many lawyers.) Furthermore, it is safe to assume that clients generally dislike lawyers who disclose. ${ }^{9}$ A lawyer who discloses therefore incurs an expected cost in the form of lost fee revenue from prospective clients who, knowing the lawyer is willing to disclose, opt for more tight-lipped counsel. ${ }^{10}$ (This cost may be considered a reduction in the value of the lawyer's reputation.) I will refer collectively to the sum of lost fees from an unlawful deal on which the lawyer blows the whistle, the present value of future fees from that client, and the present value of fees from future clients who hire someone else because the lawyer disclosed, as the "expected cost of lost fees."

How does the expected cost of lost fees affect a lawyer's decision to disclose? The answer depends on the composition of the lawyer's client base. In general, the degree to which the expected cost of lost fees influences a particular lawyer's behavior will vary inversely with the degree to which her client base is diversified. The expected cost of lost fees will dis-

8. The lawyer's loss of fees would also depend on the client's solvency-whether the client could have paid cven absent disclosure - and the lawyer's willingness to sue a client for fees, which might further harm the lawyer's reputation.

9. See discussion infra Part l.B.

10. On the role of lawyers' reputations in ethics analysis, see George M. Cohen, When Law and Economics Met Professional Responsibility, 67 FordHAM L. REv. 273, 288 (1998). 
courage disclosure more if the client engaging in the misconduct represents $50 \%$ of the lawyer's income than if the client represents only $5 \%$ of her income. The extreme case, then, is in-house counsel, where the client probably represents $100 \%$ of the lawyer's income. The expected cost of lost fees is therefore likely to influence decisions by in-house counsel more than decisions by outside counsel. ${ }^{11}$ Whatever the relative degree of influence, however, any economically rational attomey will consider the expected cost of lost fees in deciding whether to disclose client financial misconduct.

\section{Disclosure Increases the Expected Cost of Litigation}

The second type of cost involves liability. A lawyer's disclosure of a client's financial misconduct increases the likelihood that third parties, such as investors (or, in the case of conduct such as price-fixing, consumers) will sue the client and, perhaps, the lawyer too. Why? Absent disclosure, third parties may not know their losses are due to unlawful conduct. Once they have reason to believe they are victims of illegal conduct, however, they are more likely to sue.

\section{a. The Lawyer's Risk of Liability}

While clients bear the greatest risk of being sued if a lawyer discloses, lawyers risk liability as well. I will analyze this risk using our earlier example of a fraudulent investment scheme. In some cases, defrauded investors might sue an issuer's lawyers, as well as the issuer itself, under the federal securities laws. Central Bank of Denver v. First Interstate Bank of Denver $^{12}$ limits such claims to cases where a lawyer personally communicated with investors ${ }^{13}$ or wrote a lie himself. ${ }^{14}$ Nevertheless, some investors will have sound claims against an issuer's lawyers. Plaintiffs' counsel cannot know all the drafters of disclosure documents before discovery begins, so even more lawyers face a risk of being named as a defendant. These lawyers would incur litigation costs, even if they eventually prevailed on summary judgment. A lawyer who discloses in such cases would therefore create a risk of federal civil liability for himself. ${ }^{15}$ In some cases, lawyers

11. See discussion infra Part II.C.

I2. 511 U.S. I64, I9I (1994) (holding that SEC Rule I0b-5 does not create a cause of action for aiding and abetting a violation of the rule).

13. See, e.g., Rubin v. Schottenstein, Zox \& Dunn, I43 F.3d 263 (6th Cir. 1998) (finding that defrauded investors could pursue federal securities law claim against lawyer who made a representation to investors).

14. In re Enron Corp. Sec., Derivative \& ERISA Litig., 235 F. Supp. 2d 549, 582-9I (S.D. Tex. 2002) (adopting standard of liability proposed by SEC under which a person who acts with scienter in creating a misstatement may be held liable as a primary violator).

15. This risk would be greater (adding bite to my proposal) if Central Bank were overruled, which 1 think it should be. It is bad seeurities law and fosters bad ethics. For criticism of the case from a securities law perspective, see Donald C. Langevoort, Agency Law Inside the Corporation: Problems 
may also face state law investor claims for aiding and abetting constituent misconduct or for conspiring with constituents to engage in misconduct. ${ }^{16}$ For conduct not subject to the Central Bank limitation, such as price fixing, the risk would be correspondingly greater.

In addition, if a client goes under, a bankruptcy trustee might sue the disclosing lawyer for malpractice or for aiding and abetting a breach of fiduciary duty by corporate officials. ${ }^{17}$ Whether or when the client goes under might depend on whether the lawyer notifies investors of misconduct. ${ }^{18}$ Suppose, for example, the client needs to close a fraudulent deal to stay afloat. If the lawyer stays silent, the client might get lucky and use the fraudulently obtained funds to turn its business around. If it did, investors would not lose money, and no one would be the wiser. Disclosing, however, could signal to capital markets, trade creditors, and others that the client is in trouble. That perception could become a self-fulfilling prophecy: disclosure might trigger the collapse that would then create the expected cost of litigation, while silence might forestall or avoid it entirely.

In extreme cases, a lawyer might also risk disciplinary action or even criminal liability for helping a client commit a fraud. ${ }^{19}$ I will refer collectively to the combination of risks of liability for malpractice, aiding and abetting, disciplinary actions, and damage suits the "expected cost of litigation."

\section{b. Qualifications to the Increased Expected Cost of Litigation}

Some qualifications apply to calculating the expected cost of litigation. First, the risk of litigation is hard to quantify, so the expected cost of litigation is harder to estimate than the expected cost of lost fees. While it is a short and predictable step from a lawyer's disclosure of financial misconduct to the client firing him, resulting in lost fee income, third parties

of Candor and Knowledge, 71 U. CIN. L. REv. 1187, 1227-28 (2003). For criticism of the case from an ethical perspective, see Crampton, supra note 2.

16. See Granewich v. Harding, 985 P.2d 788 (Or. 1999) (recognizing a cause of action by minority shareholder against entity counsel for aiding and abetting alleged breach of fiduciary duty in connection with freeze-out transaction); Chem-Age lndus., lnc. v. Glover, 652 N.W.2d 756 (S.D. 2002).

17. See, e.g., Chem-Age, 652 N.W.2d at 773-76 (discussing attorney liability for aiding and abetting breach of duty); RESTATEMENT (SECOND) OF TORTS $\$$ 876(b) (1979) (describing liability for assisting tortious conduct of others). The Ninth Circuit recognized such a theory in FDIC $v$. O'Melveny \& Myers, 969 F.2d 744 (9th Cir. 1992), but in Loyd v. Paine Webber, Inc., 208 F.3d 755 (9th Cir. 2000), it limited $O^{\prime}$ Melveny to little more than its facts. For a plaintiff-oriented summary of the law in such cases, see Final Report of Neal Batson, Appendix C, Annex 1, In re Enron Corp., (S.D.N.Y. 2001) (No. 01-16034) (copy on file with author).

18. See Daniel R. Fischel, Lawyers and Confidentiality, 65 U. CHI. L. REv. 1, 12 (1998) ("Lawyers have expanded confidentiality obligations to avoid being sued.").

19. See MODEL RULES OF PROF'L CONDUCT R. 1.2(d) (2003) (forbidding lawyers from assisting clients in fraudulent acts); United States v. Benjamin, 328 F.2d 854 (2d Cir. 1964) (affirming eonvictions of lawyer participating in securities fraud), cert. denied sub nom., Howard v. United States, 377 U.S. 953 (1964). 
are not likely to sue lawyers unless there is significant financial loss and circumstances suggest to investors that some law was broken and a lawyer had a hand in breaking it. A rational lawyer might consider civil liability, criminal conviction, or administrative discipline to be very unlikely, and thus to have a lower expected cost than the loss of fee income, even if the nominal cost of such sanctions would be higher than the expected cost of lost fees.

Second, silence is not risk-free. Some schemes blow up and lead to suits against lawyers even though the lawyers said nothing. I will refer to the risk of litigation without disclosure as the "baseline risk of litigation." Baseline risk varies by factors such as the type of transaction, how much money is at stake, and the aggressiveness of government enforcement officials. The expected cost of litigation refers to the difference between the baseline risk of litigation against the lawyer and the risk of litigation if the lawyer discloses.

Third, unlike the expected cost of lost fees, the expected cost of litigation applies only to cases where someone suffers financial harm. If an investor does not put money into a transaction (or rely on a misstatement regarding that transaction by, for example, passing up an alternative transaction), or if a deal makes money notwithstanding fraud, then the investor has no damages and is unlikely to sue the client or the lawyer. Lack of investor or consumer harm makes government action less likely, too. The low probability of suit or government enforcement in such cases implies a low expected cost of litigation.

Fourth, the expected cost of lost fees and the expected cost of litigation interact, and their interaction affects the lawyer's decision to disclose. As described in the following section, ex ante disclosure-that is, disclosure bcfore a fraudulent deal closes-might lower the lawyer's expected cost of litigation. It will create the expected cost of lost fees, however. The two effects offset each other, and an economically rational lawyer will go forward with suspect deals whenever the expected cost of lost fees exceeds the expected cost of litigation. In cases of ex post disclosure, which occurs after third parties have been affected, fee and litigation costs work to reinforce each other to make disclosure an unattractive option. Thus, the interplay of costs in each casc may increase or decrease the likelihood of disclosure.

\section{c. The Problem of Ex Ante Disclosure}

Because the expected cost of litigation applies only when third parties have been harmed by unlawful conduct, ex ante disclosure may lower this cost. If a lawyer's disclosure keeps investors from investing in a client's scheme, in other words, they will not lose the money they did not invest. Disclosure after the scheme goes into effect (ex post disclosure) will al- 
ways raise the expected cost of litigation. A lawyer who realizes she is involved in unlawful activity that has not yet affected third parties therefore has an incentive to disclose the activity before it takes effect. ${ }^{20}$ Whether the lawyer would actually be motivated to disclose depends on whether disclosure would lower the expected cost of litigation enough to outweigh the sum of costs it would create, including, most prominently, the expected cost of lost fees.

A lawyer's decision whether to disclose ex ante can be tricky. Suppose the lawyer believes shc can persuade the client to obey the law. If the lawyer succeeds, she would avoid the expected cost of lost fees andby either creating a lawful transaction or halting an unlawful one-reduce the expected cost of litigation to the baseline risk of litigation. ${ }^{21}$ On the other hand, if the lawyer discloses and is fired, she incurs both the expected cost of lost fees and loses the chance to persuade the client to obey the law, in which case society, too, might suffer if the client manages to break the law anyway. For these reasons, a lawyer may have greater incentive to work with the client than to disclose.

Furthermore, a lawyer might not know until the last minute that the transaction is unlawful. This might occur, for example, in cases where a client agrees to provide information before the deal closes but does not follow through, or where a lawyer learns only at the last minute that the client has cooked the books. By that time, third parties may have partially invested or incurred reliance costs and therefore might have a basis to sue. In these cases, by the time the lawyer accepts that the client will not obey the law and starts thinking seriously about disclosure, she might already have litigation risk, even though she always acted in good faith and the transaction has not actually occurred. In other words, disclosure would be ex ante in the sense that it would occur before a deal closed, but it would carry part of the risk of ex post disclosure in that it would occur after investors incurred economic costs. Here I use the time of closing to divide ex ante from ex post disclosure, recognizing that ex ante disclosure reduces but

20. Some state rules, such as Minnesota's, forbid ex ante disclosure even though they allow ex post disclosure. See Minn. Rule of Prof'L Conduct R. 1.6(a)-(b)(4), State of Minnesota, available at http://www.courts.state.mn.us/lprb/conduct.html (last visited Aug. 30, 2004). Such rules are perverse because they raise costs in precisely the type of situation where a lawyer's economic incentives might otherwise prompt disclosure that would keep investors from suffering harm. For that reason alone, such rules should be changed to emulate Model Rule 1.6(b), allowing ex ante disclosure. Indeed, ex ante disclosure may be the only way to "prevent substantial injury to" clients, which is a condition to lawyer disclosure under amended Model Rule 1.13(c). Ex post disclosure will usually lead to suits against clients, creating substantial injury rather than preventing it. If disclosure rules such as Minnesota's are to have any teeth in ex post disclosure cases, courts will have to adopt the legal fiction that disclosing fraud does not harm clients as a matter of law, because it certainly will not help clients as a matter of finance.

21. l assume there are some nonmeritorious suits in cases where deals close, so that cost is still positive in such cases. 
may not eliminate the expected cost of litigation. These problems will be revisited in Part III.

\section{B. Assumptions Underlying the Economic Analysis of Attorney Disclosure}

My proposal makes several assumptions. First, I assume that lawyers act rationally with regard to the economic costs and benefits of representation. That assumption seems safe to me, ${ }^{22}$ so I will simply state it and note that if lawyers do not care about such costs, my proposal will not work.

A second assumption is that clients dislike lawyers who disclose. While I am not aware of empirical research on this question, it follows from the fact that lawyers who blow the whistle on clients create costs for clients and rational clients dislike costs. Ex ante disclosure increases transaction costs by making it harder to close the deal, and ex post disclosure makes it more likely that a client will get sued, thus raising the client's expected litigation costs. Non-disclosing lawyers do not create such costs. ${ }^{23}$

On the other hand, perhaps a disclosing lawyer would benefit his clients by developing a reputation that would signal third parties that his clients' transactions are trustworthy. ${ }^{24}$ If such benefits were great enough to outweigh the costs of disclosure, however, I would expect disclosure to be more common in states that allow it, but it is not. ${ }^{25}$ Similarly, if clients favor firms that disclose, they would substitute those firms for non-disclosing firms, which presumably would lose business when their clients suffered serious meltdowns. I am not aware of any solid evidence of such a substitution effect, however. ${ }^{26}$ This suggests that the assumption that clients dislike lawyers who disclose is reasonable. To the extent this assumption is wrong, however, my argument is weakened.

Third, my proposal rests on one other factual premise: in the modern economy large-scale financial misconduct requires cooperation among professionals such as lawyers, accountants, and investment bankers. ${ }^{27}$ If a client could pull off a scheme with only a lawyer's help, my proposal would

22. Cf. Gen. Dynamics Corp. v. Superior Court, 876 P.2d 487, 501 (Cal. 1994) (recognizing a wrongful discharge claim for in-house counsel in part to counteract the "considerable economic and cultural pressures ... to silently conform" to workplace norms).

23. This effect might be limited if these lawyers can persuade prospective clients that they only expose clients who engage in very bad acts.

24. Cf. Fischel, supra note 18 , at 19 (noting role of lawyers as reputational intermediaries).

25. Koniak, When the Hurlyburly's Done: The Bar's Struggle with the SEC, supra note 3, at 21516.

26. A recent news account has Vinson \& Elkins lawyers speculating that they might have lost some business because they represented Enron. Miriam Rozen \& Brenda Sapino Jeffreys, Law Firm Fighting the Ghost of Enron, LEGAL TIMEs, Dec. 29, 2003, at 1 . The story cites a $5 \%$ reduction in revenues, but also notes that the reduction coincided with a recession. Given the unusually bad publicity this firm received, it is significant that there is no unambiguous evidence that clients fired it for its Enron connections.

27. Koniak, Corporate Fraud: See, Lawyers, supra note 3, at 227 
not work as well as it does in more common cases involving multiple players. Lastly, my proposal rests on a philosophical premise: lawyers who cooperate in misconduct, whether passively or actively, should be treated no differently than any other conspirator. I explain and defend this premise in Part III.

\section{Financial Misconduct as a Cooperation Game}

My proposal conceives of the client fraud case as analogous to a cooperation game. ${ }^{28}$ The proposal is designed to erode cooperation among players and create a prisoner's dilemma. ${ }^{29}$ Here is how the system currently works: Suppose a client wishes to close a fraudulent investment. The client's payoff comes from investment revenues when the transaction closes; the lawyer's payoff comes from fees on the transaction, the present value of expected future fees from that client, and reputational gains from being considered experienced with a type of transaction. If the client and lawyer cooperate and the scheme succeeds undetected, the investors are defrauded and the client and lawyer each get their payoff. As things stand now, even with the 2003 amendments to the Model Rules, and even if the deal is unlawful, no one has an incentive to disclose.

\section{The Unlikelihood of Client Disclosure}

If the client discloses a fraud before the deal closes, the client incurs the opportunity cost of Iosing the revenue from the deal. It may also incur investor reliance costs and the expected cost of discipline by a government agency. The effect on the lawyer, on the other hand, is unclear. The client's lawyer may or may not be entitled to fees on the transaction at issue. ${ }^{30}$ Such a case would probably have ambiguous effects on the lawyer's reputation and expectation of future fees froin the client. If clients generally like non-disclosing lawyers, client disclosure might actually enhance the value of the lawyer's reputation. On the other hand, if even client officers could not stomach a certain deal, while a non-disclosing lawyer could, the lawyer might seem well outside even the generous standards of business ethics. That perception might lead the existing client and others to look for more palatable counsel.

28. Professor Cohen treats this problem as one of "collusion" as well. Cohen, supra note 10, at 296-97. My proposal can be viewed in light of his insightful observation that "lawyer self-interest means that the absence of lawyer-client collusion cannot merely be assumed, but must be actively secured." Id. at 295.

29. This idea is not entirely novel. It has been used with great success in the antitrust rules to fight cartels. See Christopher R. Leslie, Trust, Distrust, and Antitrust, 82 TEx. L. REv. 515 (2004).

30. If a lawyer or firm violated a duty or ethical rule (such as Model Rule 1.2(d)) in connection with the transaction, it is conceivable that a client could resist payment of fees on the ground of the violation even though the client was committing the fraud. See RESTATEMENT (THIRD) OF THE LAW GOVERNING LAWYERS $\S 37$ (2000). 
Client disclosure cases are probably very rare, if they happen at all. After all, why would the client disclose if it wanted to defraud investors or if it believed the transaction was lawful? For the same reasons, ex post client disclosure is likely rarer still. The lawyer therefore can assume the client will not disclose.

\section{The Costs of Attorney Disclosure}

If the lawyer discloses the fraud before the deal closes, she incurs the expected cost of lost fees but may lower her expected cost of litigation relative to the baseline cost if she did not disclose. If the expected cost of lost fees is low, and if disclosure reduces expected costs of litigation, then the lawyer maximizes revenue by disclosing when the client is silent.

Even under the new Model Rules, however, ex ante disclosure is unlikely since, as noted above, ex ante disclosure is more difficult than it seems. ${ }^{31}$ More fundamentally, the expected cost of lost fees will probably be significant in most cases. It is therefore likely that staying silent will produce the best economic outcome for the lawyer as well as the client, because silence minimizes the sum of the lawyer's expected costs relative to the sum of expected costs generated by disclosure.

If the lawyer discloses after the deal, she will incur the expected cost of lost fees and the expected cost of litigation, as described in Part I.A. Therefore, the likelihood of either the lawyer or the client disclosing ex post is small. In the even more unlikely possibility that both parties disclose, the lawyer would suffer some reputational cost from demonstrating a willingness to disclose and some expected cost of litigation. The expected cost of lost fees would be uncertain, however, given the client's disclosure in this scenario.

\section{Disclosure by Other Professionals}

Attorneys are not the only professionals who help scams succeed: accountants and investment bankers play critical roles, too. Though client constituents have little if any incentive to disclose their own misconduct, accountants and bankers have incentive structures more similar to those facing lawyers. ${ }^{32}$ All professionals must worry about the risk of losing fees from existing clients, losing opportunities to earn fees from prospective clients, and getting sued in cases of client misconduct.

In the following table, the columns depict the incentives of nonlawyer professionals (NLPs) in a fraudulent transaction. The column players could be issuer constituents, but I believe they are more likely to be accountants, bankers, or other providers of professional services.

\footnotetext{
31. See discussion supra Part I.A.5.

32. There are some significant differences, of course. For example, an underwriter who actually purchases and re-sells securities faces economic risks lawyers do not.
} 


\begin{tabular}{|c|c|c|c|}
\hline & NLP silent & $\begin{array}{l}\text { NLP discloses } \\
\text { ex ante }\end{array}$ & $\begin{array}{l}\text { NLP discloses } \\
\text { ex post }\end{array}$ \\
\hline $\begin{array}{l}\text { Lawyer } \\
\text { silent }\end{array}$ & $\begin{array}{l}\text { All parties earn } \\
\text { payoff; bear } \\
\text { baseline litigation } \\
\text { risk }\end{array}$ & $\begin{array}{l}\text { NLP: Expected } \\
\text { cost of lost fees; } \\
\text { expected cost of } \\
\text { litigation } \\
\text { Lawyer: No } \\
\text { expected cost of } \\
\text { lost fees; expected } \\
\text { cost of litigation }\end{array}$ & $\begin{array}{l}\text { NLP: Expected } \\
\text { cost of lost fees; } \\
\text { expected cost of } \\
\text { litigation } \\
\text { Lawyer: No } \\
\text { expected cost of } \\
\text { lost fees; expected } \\
\text { cost of litigation }\end{array}$ \\
\hline $\begin{array}{l}\text { Lawyer } \\
\text { discloses ex } \\
\text { ante }\end{array}$ & $\begin{array}{l}\text { NLP: No expected } \\
\text { cost of lost fees; } \\
\text { expected cost of } \\
\text { litigation } \\
\text { Lawyer: Expected } \\
\text { cost of lost fees; } \\
\text { expected cost of } \\
\text { litigation }\end{array}$ & $\begin{array}{l}\text { Both parties incur } \\
\text { expected cost of } \\
\text { lost fees and } \\
\text { expected cost of } \\
\text { litigation }\end{array}$ & Not applicable \\
\hline $\begin{array}{l}\text { Lawyer } \\
\text { discloses } \\
\text { ex post }\end{array}$ & $\begin{array}{l}\text { NLP: No } \\
\text { expected cost of } \\
\text { lost fees; expected } \\
\text { cost of litigation } \\
\text { Lawyer: Expected } \\
\text { cost of lost fees; } \\
\text { expected cost of } \\
\text { litigation }\end{array}$ & Not applicable & $\begin{array}{l}\text { Both parties incur } \\
\text { expected cost of } \\
\text { lost fees and } \\
\text { expected cost of } \\
\text { litigation }\end{array}$ \\
\hline
\end{tabular}

As in the standard prisoner's dilemma game, both lawyers and nonlawyer professionals benefit the most economically by cooperating and staying silent. Professionals incur no expected cost of lost fees, and no player incurs a marginal increase in the expected cost of litigation 
(relative to the baseline risk). As long as disclosure creates any increased litigation risk, which will almost always be the case, staying silent is best for all concerned.$^{33}$ Unlike the standard prisoner's dilemma game, however, the players in this game can coordinate their actions. Under existing rules, cooperation should be effective. There is no reason for one player to fear that another will break a promise of silence (express or implied), because each player knows that silence is the profit-maximizing play for every other player. Though optimal for the participants, cooperation is bad for investors and (by misallocating investment funds to fraudulently inflated purposes) for society in general.

To the extent the table depicts the real world, the amended Model Rules 1.6 and 1.13 will not increase lawyers' disclosure of client fraud. To increase lawyer disclosure in cases of client misconduct we must adopt rules that provide economic incentives that push a lawyer's profitmaximizing strategy away from silence to either ex ante disclosure (optimally) or ex post disclosure (at least better than silence). Rules that accomplish this result would affect the behavior of every participant in a scam. If clients and non-lawyer professionals know that even lawyers who promise to stay silent have an incentive to disclose, they will be less likely to trust lawyers not to disclose. The risk of defection would create distrust among scheme participants, making the fraud game harder to play. Consequently, rules generating such distrust would make fraud less likely in transactions involving lawyers than is the case under the current rules.

How do we shift the lawyer's strategy away from silence? By lowering the costs of disclosure to the point where the lawyer is better off disclosing than staying silent. In other words, the lawyer's disclosure is unlikely unless the law makes it economically rational for the lawyer to disclose.

\section{II}

\section{The Proposal}

My proposal increases the lawyer's incentive by targeting the expected cost of litigation. The federal and state governments should enact laws giving immunity from civil, criminal, and administrative liability to the first party who discloses misconduct, unless a government agency with jurisdiction over the misconduct already has sufficient evidence to bring a case against the client. The immunity should extend to any claim related to the disclosed misconduct.

33. Without an immunity rule, this is true even if the expected cost of lost fees is relatively low (if the client is about to go under, for example, so it will not generate future fees), as long as the nominal cost of litigation is very high, as would arise from a truly serious scam, for example. In that case, any increased probability of litigation would produce significant increases in the expected cost of litigation. 
Although lawyers are my subject here, to maximize the effect of my proposal, all parties involved in a scheme should be eligible for immunity. If another party discloses first-whether the client or some other participant, such as an investment banker or accountant-the disclosing party should receive immunity and the lawyer should not. Non-disclosing participants should pay (in proportion to their liability share) any damages otherwise attributable to the disclosing party.

This immunity is designed to eliminate the first discloser's expected cost of litigation. If a lawyer knows that by disclosing misconduct first she could avoid costs, she will be much more likely to do so. The client, aware of the lawyer's options, will be less able to trust the lawyer not to disclose, even if the lawyer makes an explicit promise to cooperate with the scheme. The same applies to other professionals, such as accountants or investment bankers. The lack of trust among participants will make it harder to coordinate the players needed to implement financial schemes, making it less likely that schemes harming investors will succeed.

\section{A. Antitrust Law as a Model for Using Immunity To Increase Disclosure}

The model for this proposal is the "Corporate Leniency Policy" adopted by the Antitrust Division of the Department of Justice (DOJ). ${ }^{34}$ Under that policy, if a party to a violation of the antitrust laws meets certain conditions, it receives immunity from criminal prosecution. ${ }^{35}$ For firms reporting before the Division learns of a violation, immunity is granted only if: (I) the Antitrust Division had not received information about the violation from another source; (2) the firm promptly terminated its participation in the scheme when it learned about the scheme; (3) the firm "reports the wrongdoing with candor and completeness and provides full, continuing and complete cooperation that advances the Division in its investigation"36; (4) the confession is a truly corporate act rather than the act of a particular employee; (5) where possible, the firm makes restitution to injured parties; and (6) the firm did not initiate the violation, participate as the lead player, or coerce others to violate the law. ${ }^{37}$

34. U.S. DeP'T of Justice, Corporate Leniency Policy (Aug. 10, 1993), available at http://www.usdoj.gov/atr/public/guidelines/0091.pdf (last visited Aug. 28, 2004).

35. Id. For a description of how the policy works, see Gary R. Spratling, The Corporate Leniency Policy: Answers to Recurring Questions, U.S. Department of Justice, at http:// www.usdoj.gov/atr/public/speeches/1626.htm (Apr. 1, 1998). For an analysis relating the policy to issues of trust between parties and the creation of a prisoners' dilemma, see Leslie, supra note 29 , at 639-42.

36. U.S. DeP'T of Justice, Corporate Leniency Policy, supra note 34 , at 3.

37. Id. at 2-3. Alternative standards for leniency apply when an applicant cannot meet these standards, usually because the Division is investigating the violation already. In such a case, the applicant must satisfy standards (2) through (5) and also be the first one to report the violation. In such a case, the Division will grant leniency if it did not already have enough evidence to provc a violation and if it determines that granting leniency to the applicant would not be unfair to others. The policy for 
The DOJ's Corporate Leniency Policy has worked well. In congressional testimony in September 2002, Assistant Attorney General Charles James described the program as an "extraordinary success," stating that it "has played a major role in cracking the majority of the international cartels that the Division has prosecuted." ${ }^{\prime 38}$ In fact, James reported that the Division's program is being used as a model for antitrust enforcers around the world.$^{39}$ In a 1998 speech, Deputy Assistant Attorney General Gary Spratling said the Division received corporate amnesty applications about once a month, and the applications concerned violations that became the largest cases on the Division's docket. ${ }^{40}$

Because lawyer disclosure of client financial misconduct differs in some ways from the antitrust violations the DOJ's rules target, my proposal deviates somewhat from the antitrust leniency rules. Most obviously, the antitrust rules are aimed at primary violators rather than their lawyers. ${ }^{41}$ Furthermore, the antitrust rules provide immunity from prosecution and government fines, but not from civil liability. In fact, the DOJ's rules require restitution where possible. My proposal, on the other hand, eliminates civil as well as criminal liability since lawyers are only rarely prosecuted for their role in client fraud. ${ }^{42}$

\section{B. The Details of the Immunity "Carrot"}

I will now define the proposal more precisely. This section describes how far immunity would extend, what would have to be done to obtain it, and how I would combat a risk my proposal might create.

individuals grants leniency to persons who report violations about which the Division has not received information from another source and who satisfy requirements similar to elements (3) and (6) of the corporate policy.

38. Oversight of Enforcement of the Antitrust Laws: Hearing Before the Subcomm. on Antitrust, Bus. Rights, and Competition of the Senate Comm. on the Judiciary, 107th Cong. 159 (2003) (statement of Charles A. James, Assistant Attorney General, Antitrust Division).

39. Id. at 159-60. Consider, for example, the Division's grant of leniency to Christie's, which disclosed its price-fixing schemc with Sotheby's in October 2000. Sotheby's was subsequently indicted, while Christie's was not. See Press Release, U.S. Department of Justice, Sotheby's and Former Top Executive Agree to Plead Guilty to Price Fixing on Commissions Charged to Sellers at Auctions (Oct. 5, 2000), available at http://www.usdoj.gov/opa/pr/2000/October/59 1at.htm (last visited Aug. 28, 2004).

40. Spratling, supra note 35.

41. Unless, of course, lawyers are fixing prices themselves. $C f$. Goldfarb v. Va. State Bar, 421 U.S. 773 (1975).

42. Koniak, Corporate Fraud: See, Lawyers, supra note 3, at 215; but see, e.g., United States v. Frank, 494 F.2d 145 (2d Cir. 1974). 


\section{The Scope of the Proposed Immunity}

Immunity means what it says: a lawyer who is the first to report misconduct would not be held liable in connection with that misconduct. ${ }^{43}$ The lawyer could assert his report of the misconduct as a complete defense to any indictment, civil cause of action, or disciplinary action related to the reported misconduct. Judges would examine the facts alleged in indictments and complaints and carve out any claims, or even allegations, related to the disclosed misconduct.

Although a judge or administrator may have to determine the scope of immunity, the grant of immunity itself should not be left to the discretion of a judge or administrator. Such discretion creates a risk that immunity will not be granted, which lessens the attractiveness of disclosure. I would allow an exception to the rule of absolute immunity, however: if a government enforcer has already collected enough evidence to establish the elements of the misconduct by the time a party discloses, the disclosing party should not get immunity. If the government already has a strong case, the marginal public value of disclosure would be small and would not justify the costs of granting immunity. In addition, because it takes time for the government to build a case, this condition also places a premium on early disclosure, which may be a party's only hope for immunity and is more valuable to enforcement officials than late disclosure because it may save them work. The incentive to disclose early reinforces the trust-eroding effect of this proposal. This condition might create some risk that a report will not produce immunity, which therefore might also lessen the advantage of reporting, but government officials can pursue only a small fraction of misconduct, so this risk would likely be small. Furthermore, the government should bear the burden of showing that it has the information needed to proceed with its case.

In addition to the conduct reported, immunity should also extend to the report itself. Providing immunity for the report would encourage disclosure in cases where the reported conduct turns out to be lawful and the client wants to sue the lawyer. ${ }^{44}$ However, such "false positive" reports would likely be extremely rare. ${ }^{45}$

\section{Procedures for Disclosure}

To receive the proposed immunity the lawyer should make the disclosure to a government official with jurisdiction over the misconduct. Depending on the facts, the official could be a member of the SEC or

43. Financial misconduct excludes criminal activity resulting in physical harm. Prosecutors have the power to cut deals in such cases, and 1 would not suggest anything to affect their discretion.

44. Section $10 A(c)$ of the Securities Exchange Act, which immunizes accountants for liability for reports the Act requires, provides analogous support for this rule.

45. See infra Part III.B. 
Federal Trade Commission (FTC), a state securities regulator, the Department of Justice, a banking regulator, or a local district attorney. Immunity should work across governmental lines. Disclosing to a qualified federal official should work for both federal and state issues, and vice versa. The lawyer should send a copy of the disclosure to the client, who should be required to publicize the disclosure, for example by filing a Form 8-K or by issuing a press release. ${ }^{46}$ Each disclosure report should be dated, and faking or doctoring a report should be punished severely.

\section{Disclosure Requirements}

Disclosure must be meaningful. As with the antitrust leniency rules, anything less than a complete and candid report should not receive immunity. This obligation should continue as long as any claims related to the reported misconduct are pending. Disclosing counsel should be required to cooperate in good faith with any investigation of the reported misconduct, including any investigation by counsel representing plaintiffs harmed by the misconduct. These obligations should extend to require the Iawyer to testify in proceedings related to the misconduct in question. A disclosing lawyer who cooperates initially but later refuses to cooperate should lose immunity altogether. ${ }^{47}$

Only the first party to disclose misconduct should receive immunity. The purpose of my proposal is to erode trust among participants in schemes where trust makes it possible for misconduct to occur. Limiting immunity to the first discloser will maximize the degree of distrust since each participant will know he will be Ieft holding the bag if another participant discloses first. Furthermore, each participant also knows that the others face the same choice. The pressure to jump first to secure immunity will therefore be high. Additionally, in most cases the information provided by subsequent disclosers will probably duplicate much of the information already obtained from the first discloser, so the marginaI social gain

\footnotetext{
46. This idea tracks a feature of the SEC's proposed whistle-blowing rule, which requires counsel to report to the client, who is then required to file notice with the SEC on Form 8-K. See U.S. Securities and Exchange Commission, Proposed Rule: Implementation of Standards of Professional Conduct for Attorneys, at http://www.sec.gov/rules/proposed/33-8I86.htm (last modified Sept. 26, 2003) (describing the proposed rule and soliciting public comment). For firms in the SEC's reporting regime, 8-K disclosure would work also. For other firms, press releases, or other means of widespread disclosure, such as a website posting, would satisfy the requirement.

47. I would not grant immunity to any counsel that reported only to the client under Model Rule I.13, or who reported "up the ladder" to officers or directors of an entity client and then withdrew. Nor should lawyers who withdraw from representation and notify third parties who might rely on the lawyer's work product receive immunity. Cf. N.Y. Code Prof. RESP. $\$$ I200.19(c)(5) (Oceana 2003) (permitting disclosure of confidences or secrets to the extent implicit in withdrawing work product on which third parties might rely). "Noisy withdrawal" is a red flag that misconduct is occurring-in some cases a powerful one-but it is not the same as full disclosure. A lawyer who wants immunity should have to remove any ambiguity by disclosing entircly.
} 
from their disclosure would be lower than the marginal gain from the first discloser. ${ }^{48}$

Finally, any gap between reports should be enough to establish priority and thus immunity. A party who is first by five minute is still first. In the unIikely case of literally simultaneous reports from different players, neither should receive immunity unless they can rebut the presumption (justified by the improbability of simultaneous reports) that their reports were coordinated. This rule should deter coordinated reports, and contribute to the pressure to be the first to disclose.

\section{The Risk of Coercion}

Coercion between parties might make my proposal less effective. If one party learns that another is about to make a report, the first party might coerce the other into remaining silent. In such a case, I would not grant immunity to the party who was coerced into silence, because the party would not have created a public benefit by reporting the misconduct. If that party could prove by a preponderance of the evidence that it would have reported but for the coercion, however, it should get a right of indemnity against the coercing party. So long as the coercing party remained solvent, the coerced party would escape financial liability, the public would not suffer any loss, and the coercing party would bear the costs of its coercion.

\section{Addressing the Expected Cost of Lost Fees}

Although I discuss objections to my proposal more thoroughly in Part III, I will note one significant issue here: the proposal deals with the expected cost of litigation but not with the expected cost of lost fees. It therefore does not induce lawyer disclosure as much as it would if the disclosing lawyers could recover that cost. To strengthen Iawyers' incentives even further, the proposal could be modified to give disclosing lawyers a claim against the client engaged in misconduct for the present value of fees over a reasonable time horizon. This would lower the expected cost of lost fees from the client in addition to the proposal's reduction of the expected cost of litigation. Even this modification wouId not compensate the lawyer for reputational costs, however.

Nevertheless, I am against permitting the disclosing attorney to sue the client for fee replacement. My proposal already invites the sound objec-

48. Professor Leslie disagrees with this analysis, arguing that confession is not a dominant strategy (meaning the best move for a party regardless of what it expects other parties to do) unless a firm is always better off confessing than staying silent, regardless of what co-conspirators do. Leslie, supra note 29 , at 639 . It is true that under my proposal an executive who believes a co-conspirator has already confessed might decide to stay silent rather than cooperatc with enforcement officials. It is also truc that second-confessors may add valuable information to that provided by the first. My proposal is limited to the first confessor, however, because investors should have solvent, un-immunized parties to sue, and first-confessor immunity will tend to maximize the trust-eroding effect of the proposal. 
tion that it may harm third party consumers or investors by depriving them of a potential source of recovery. ${ }^{49}$ This modification might aggravate that harm by adding counsel to the list of parties with a claim on the client's assets.

In addition, the actual amount of fees to be replaced might be hard to calculate. One could project historical fees into the future, for example by taking the mean annual fee income over the past three years and awarding the present value of that amount at a risk-free rate over a specified number of years. As far as fees are concerned, however, past is not prologue. For example, the client might have fired the lawyer for reasons unrelated to the report. Permitting fee replacement therefore invites the objection that it would destroy client autonomy by binding an unwilling client to a lawyer, a claim analogous to criticisms sometimes raised against non-refundable fees. ${ }^{50}$

I would, however, favor fee replacement for in-house attorneys. In-house lawyers have less diverse sources of revenue than outside firms. If they are fired, they may have no other fee income. The expected cost of lost fees will therefore be a greater barrier to disclosure for an in-house lawyer than for outside counsel. If clients understand this fact, clients intending to engage in misconduct might substitute in-house attorneys for outside counsel. If outside counsel provided more efficient service, this substitution would reduce society's overall welfare. The key to fighting substitution is equalizing the probability of a report, so I would favor awarding a reporting in-house attorney a claim against her client if the attorney suffers adverse employment action by reason of the report. ${ }^{51}$

\section{III}

\section{Objections to the Proposal}

This Part discusses objections to my proposal. The main objections are that grants of immunity may harm investors, erode trust between lawyers and clients, and lead to less effective legal representation.

\section{A. Immunity May Deprive Investors of Recovery}

The most serious objection to this proposal is that granting immunity to lawyers might hurt investors and consumers. If a lawyer discloses financial misconduct and the client goes under as a result of this misconduct, granting the lawyer immunity might deny plaintiffs damages they other-

49. See infra Part III.A.

50. See Cohen v. Radio-Elecs. Officers Union, Dist. 3, 679 A.2d I188 (N.J. I996) (raising this objection).

5I. By "adverse employment action," I mean to refer to the standards employed in Title VII litigation. Any amount would be somewhat arbitrary. As a default, I would award the present value of five years' wages at the rate of payment at the time of the report. That should be much more than enough time for eounsel to find altermative work. 
wise would have recovered if no other solvent participants were available to be sued. That result seems both unjust and inefficient. It would be unjust because the innocent investor would suffer a loss while the wrongdoing lawyer goes unpunished. It would be inefficient because the lawyer would not bear the cost of her welfare-reducing conduct.

Another concern with my proposal is that the value of immunity, and thus the incentive to disclose, are directly proportional to the damages a lawyer might have to pay if another party discloses first or if a fraudulent scheme is exposed without disclosure. Disclosure is therefore worth more to lawyers who help clients cause a lot of harm than to lawyers who cause less harm. Because harm may correlate with moral culpability, ${ }^{52}$ my proposal may be worth more to very "bad" lawyers-either in terms of moral culpability or harm caused - than to more innocent lawyers. ${ }^{53}$

My response to this serious objection rests on several conjectures. First, complex financial misconduct requires several players, and only one will receive immunity. It seems unlikely, therefore, that there will be many cases in which the sum of the assets of potentially responsible parties is lower than the sum of the plaintiffs' claims. Non-reporting parties would make the plaintiffs whole and then could fight among themselves over the allocation of the reporting party's share of the losses.

In addition, if the attorney discloses, he would still suffer the expected cost of lost fees. If that cost were higher for truly corrupt lawyers than for lawyers who make a mistake, this cost would ameliorate somewhat the point that immunity is worth more to "bad" lawyers or those who cause substantial harm than to relatively harmless lawyers. Perhaps less culpable lawyers would have little incentive to disclose. However, the risk of joint and several liability may drive them to disclose, even if their own expected liability cost would be low. In cases where liability would not be joint and several, a lawyer would simply have to trust jurors to recognize that the lawyer did not cause much harm. In cases with complex facts involving significant losses, reliance on jurors to accurately measure the extent of the lawyer's liability may be risky. Thus, even a mostly ethical lawyer might have an economic incentive to disclose.

Second, even in cases where the client goes bankrupt and no other potentially responsible party is solvent, the actual harm to a disclosing lawyer of the proposal might not be great. The law does not impose joint and several liability in all cases. ${ }^{54}$ Where it does not, the marginal cost of my proposal to investors would be only whatever fraction of liability could

52. However, this is not necessarily so. A morally culpable lawyer can facilitate a small seam, while a lawyer who generally acts ethically might succumb to extreme pressure from a client to participate in a scam that causes great harm.

53. My thanks to Professor Stephen Bundy, who raised this objection.

54. See, e.g., 15 U.S.C. $\S 78 \mathrm{u}-4(\mathrm{f})(2)(\mathrm{A})(2000)$ (imposing joint and several liability only for knowing violations of law). 
be attributed to the disclosing party. In the case of lawyer disclosure, that fraction might not be very high: issuers and others more directly involved in the economics of a transaction, such as accountants or investment bankers, might have greater exposure. ${ }^{55}$

I admit, however, that where the disclosing party is the only solvent party, and liability otherwise would have been joint and several, my proposal could harm investors. If a jurisdiction finds this objection compelling, and consequently would not want to adopt my proposal as presented here, it could compromise by granting disclosing parties immunity from joint and several liability, so that plaintiffs could recover only for harm attributable to the disclosing party's work. ${ }^{56}$ Allocating immunity is not a precise science, so this option creates uncertainty that might lower the value of disclosure, but it would likely be better than no immunity rule at all.

Third, the proposal would benefit investors by alerting them to claims they might not have pursued since they would not have known about the claims absent disclosure. Only a fraction of financial failures involve unlawful conduct, and investors generally have no way of knowing whether poor performance is a consequence of unlawful activity or just the normal ebb and flow of markets. Lawyers who disclose misconduct help distinguish cases worth pursuing from those not worth pursuing. To the extent immunity would induce marginal disclosure that alerts investors to bring cases they might not have brought on their own, disclosure would make investors better off even if it limited their recovery.

Finally, and most importantly, on average, this proposal will result in more benefit than harm for investors and other third parties. The objective of the proposal is to make it harder for clients to engage in misconduct. In the modern economy, coordination among professionals is necessary for complex financial misconduct to succeed. ${ }^{57}$ Consequently, when coordination is difficult, misconduct becomes less likely to succeed, and therefore less likely to be attempted. Eliminating the misconduct would prevent investors from being harmed in the first place.

For these reasons, I am willing to bet that society will gain more from averting crooked deals than investors will lose from the disclosing party's immunity. Why is this bet worth making? I believe corporate scams are driven by hubristic groupthink and the adrenaline that comes from playing

55. Such parties would thus have correspondingly greater incentives to disclose than lawyers would have. The allocations of liability at trial are likely to deviate somewhat from a hypothetical ideal allocation (based on perfect information), and the risk that such parties would disclose would put pressure on other participants to disclose, too.

56. 1 am grateful to Professor Richard Painter for this suggestion.

57. Koniak, Corporate Fraud: See Lawyers, supra note 3, at 195. 
high-stakes games. ${ }^{58}$ Smart and nimble executives, who often have a history of winning high-stakes bets, tend to believe they will eventually pull their firm out of a slump if only they have the time and money to do it. So they start by lying just a little, and then a little more, and so on, each time truly (but perhaps crazily) believing in their own power to make it all work in the end..$^{59}$

If anything can derail such thinking, it is a significant risk of imminent economic harm that makes sense to economically rational executives who view business as a Hobbesian war of all against all. My proposal creates disclosure incentives that executives can easily understand and take seriously. Persons who know their conduct may be revealed should be less willing to break the law. It would give lawyers who want and have a chance to guide client behavior into lawful channels a credible threat to back up their exhortations. The proposal structures the self-interest of the parties in a way that gives reason to be optimistic about its deterrent potential, which is about the most one can hope for in such a rule.

\section{B. Immunity May Erode Client-Attorney Trust}

Another objection to my proposal is that it would erode trust between clients and lawyers. This objection was a consistent theme in law firm comments on the SEC's proposed whistle-blowing rule under section 307 of the Sarbanes-Oxley Act. ${ }^{60} \mathrm{I}$ believe this objection is weak. The proposal would tend to erode a client's trust in a lawyer; that is its very point. Sometimes trust is bad. When individuals succeed in breaking the law partly because they can trust others, the law should erode that trust. ${ }^{61}$ The antitrust leniency rules described above exemplify this point, as do the crime-fraud exception to the attorney-client privilege ${ }^{62}$ the prohibition against lawyers

58. Koniak, When the Hurlyburly's Done: The Bar's Struggle with the SEC, supra note 3, at 1237 (referring to executives in recent scandals as "reckless and dishonest cowboys"). I do not know whether any Enron lawyer or any other lawyer in recent scandals did anything wrong, and I do not intend to imply an opinion on that subject. Anyone who thinks they have a case against such a lawyer is free to file it, and we will see what happens. 1 do not think one must assume that recent cases involved guilty lawyers to favor this proposal, however. The logic should be enough.

59. For a good discussion of these points, see generally Donald C. Langevoort, The Organizational Psychology of Hyper-Competition: Corporate Irresponsibility and the Lessons of Enron, 70 GEO. WASH. L. REV. 968 (2002). My own experience in securities practice suggests that executives are keenly aware that perceptions can becomc rcality, and they quite reasonably feel that they have to play the role of cheerleader to keep morale up, lest bad expectations within the firm turn into self-fulfilling prophecies of failure.

60. See, e.g., U.S. Securities and Exchange Commission, Comments of Seventy-Seven Law Firms (Dec. 18, 2002), available at http://www.sec.gov/rules/proposed/s74502/77lawfirms 1.htm (last visited Aug. 28, 2003).

61. See, e.g., Leslie, supra note 29, at 547 (discussing when trust should be encouraged or discouraged).

62. See In re Sealed Case, I07 F.3d 46 (D.C. Cir. 1997) (discussing the crime fraud exception to the attorney-client privilege). 
assisting unlawful client activity in Model Rule 1.2(d), and the mandatory withdrawal requirement of Rule 1.16(a). These rules make sense.

A trust-eroding rule could produce social benefits in cases where trust is bad. Such a rule would only be undesirable if it caused net losses, which would only happen if losses from cases where trust is good but is eroded by my proposal were greater than the gains in cases where trust is bad. For this reason, the real issue is whether society is better off with rules that try to erode trust where it is bad, but which might also erode it in some cases where it is good, or with rules that try to preserve trust in all cases, which will include some cases where trust is bad. In other words, the real issue is the error costs of different rules.

Because the proposal does not require a lawyer to report unlawful conduct, cases in which a lawyer does not report unlawful conduct would not count as an error. Errors would occur only if lawyers reported misconduct when none actually occurred. This is the risk of a "false positive" report.

Information is the key to this analysis. The facts that distinguish between lawful and unlawful conduct are often information the client has and the lawyer does not, such as whether the client believes in revenue forecasts, has actually shipped inventory, or has agreed to fix prices. The client has to decide whether giving a lawyer information will result in helpful lawyering or erroneous disclosure. In concrete terms, the risk of false positive reports might create two types of client distrust: the client could (1) refuse to hire a lawyer, or (2) hire a lawyer and then deceive her. Distrust could generate two types of costs: the client might (1) avoid socially desirable actions it would have taken if it had hired or trusted its lawyers, or (2) the client might take action without fully or accurately informing a lawyer, when doing so would have produced greater social gains.

The first form of client distrust should be rare. Few people would proceed with a sophisticated commercial transaction-even a fraudulent onewithout a lawyer. A person who actually goes through with a fraudulent transaction is liable for any misconduct. Hiring a lawyer lowers a person's liability risk if the lawyer identifies and stops an unlawful transaction, finds a lawful means to the client's end, or provides advice that might be a defense against certain forms of liability, such as punitive damages. Perhaps more significantly, the absence of a lawyer in a transaction that usually involves a lawyer might signal to third parties that the transaction is risky, thus making it harder for the client to close the fraudulent deal. ${ }^{63}$ The proposal could strengthen this signal by suggesting a reason why the law-

63. See Koniak, Corporate Fraud: See, Lawyers, supra note 3, at 227. 
yer might be absent that would alarm potential investors. Similarly, there is little reason for an honest client to pass up a transaction. ${ }^{64}$

For these reasons, if the risk of false positive reports generated client distrust, it would most likely be of the second type-clients who deceive their lawyers-and would produce the second type of cost. Three variables are significant here. The client: (1) may or may not trust lawyers to distinguish lawful from unlawful transactions; (2) may or may not be willing to obey the law; and (3) may or may not be willing to deceive the lawyer. These variables combine to create different types of clients.

The first class of clients includes those who are willing to obey the law and who trust lawyers to distinguish between lawful and unlawful transactions. These clients generally will not deceive lawyers. ${ }^{65}$ Such clients understand that the lawyer can help them only if the lawyer has the facts, so they will provide the necessary information. A lawyer who has all the relevant facts is more likely to distinguish lawful from unlawful transactions than is an uninformed lawyer, and therefore less likely to disclose lawful client conduct by mistake. Some lawyers might make mistakes even with full information, but competition among lawyers should weed these lawyers out over time. ${ }^{66}$

In addition, as noted earlier, the immunity proposal lowers the expected cost of litigation but does not address the expected cost of lost fees. Reporting financial fraud would still be costly to outside lawyers, and they will still have to consider carefully whether they should blow the whistle. They would likely only do so when the expected cost of litigation is very high, which will generally happen only when the probability of liability is very high. This, in turn, implies that lawyers will disclose only when they are confident that clients are breaking the law. ${ }^{67}$

64. It is possible that honest clients might distrust the legal system so much that any increased risk of disclosure would deter them from doing a deal. I doubt real-world clients are such radical legal skeptics, however. It is hard to imagine how they would get anything done if they were.

65. Cf. Fischel, supra note 18, at 29 ("Clients who seek legal advice to conform their conduct to law before they act have no need for confidentiality rules because they face no sanctions."). Such clients still might dislike disclosing lawyers because of the costs described in Part I. However, if they understand that their own disclosure decisions affect the risk of a false positive, and if they can find a lawyer they can trust, they will be unwilling to deceive their lawyer.

66. Even if fully informed lawyers make mistakes, I would not expect such mistakes to systematically favor silence or disclosure. To the extent my proposal provides an incentive to disclose, however, it might push decisions closer toward disclosure when compared to the current regime. If I am right that clients dislike disclosure, however, then lawyers who make such mistakes will lose business, and the problem should diminish over time. One might even argue that lawyers who make faise positive reports identify themselves as less competent than other lawyers, and that this informationdisclosing effect is itself socially desirable. I am grateful to Mark Lemley for pressing me on this point.

67. This logic applies less obviously to in-house lawyers, whose expected costs of lost fees my proposal would cover to some extent. On average these lawyers tend to engage in relatively routine transactions that should not pose large risks of illegality, and therefore should not generate many, if any, false reports. If a jurisdiction saw a pattern of erroneous reports from in-house lawyers, however, it could always revisit the decision to cover the expected cost of lost fees for these lawyers. 
Honest clients therefore should not be too worried that lawyers will generate false positive reports. The lawyer is more likely than the client to distinguish lawful from unlawful transactions. Consequently, competition and the cost of disclosure give lawyers incentive to only blow the whistle in cases of unambiguous and costly misconduct. The proposal therefore should not generate significant error costs either from false positive reports or from cases in which honest clients either avoid transactions or proceed without counsel.

As these points suggest, my proposal presumes that most clients are basically honest, and that headline-grabbing financial meltdowns are generated by relatively few bad apples who are willing to break the law. The proposal is tailored to target those few clients and their lawyers. Admittedly, to the extent the proposal increases the risk that lawyers will disclose, it will also increase the risk that clients will deceive. ${ }^{68} \mathrm{~A}$ client who is willing to break the law would likely also be willing to deceive her lawyers. Lawyers cannot disclose what they do not know, and deceit might make an unlawful transaction undetectable even to a very diligent lawyer. Savvy clients will therefore have strong incentives to deceive the lawyer to prevent her from disclosing.

In measuring the marginal effect of the proposal in creating situations where the client deceives the lawyer, however, it is important to remember that bad-actor clients bear risk under the existing rules. Under the current rules, lawyers may not assist in the commission of fraud and must withdraw if the representation would result in unlawful conduct. In many states, lawyers are permitted to disclose facts necessary to rectify client fraud, and communications furthering a crime or fraud are not privileged. Clients determined to commit fraud already have reason to deceive their lawyers under the current rules. The proposal outlined in this paper, therefore, may create greater client incentive to deceive lawyers, but perhaps not much greater than the incentive that already exists.

Moreover, if my proposal only erodes trust where the client is a bad actor, then it is well-tailored to cases in which trust is undesirable. Such cases are unlikely to produce false positive reports, because any report is likely to disclose real misconduct. Trust-preserving rules would be desirable in such cases only if the marginal trust they created actually helped lawyers persuade such clients to obey the law. That might happen, for example, if an informed lawyer could find some lawful way for the client to realize an equivalent (risk-adjusted) yield from the transaction. Any social

68. Client concealment can also harm lawyers. Even if a lawyer does nothing wrong but is tricked by a wily client, a judge or jury could still decide the lawyer is liablc for misconduct. Depending on the nature and size of tbe financial meltdown, a tricked lawyer could still face a suit that has substantial settlement value. 
gains generated by a shift from an unlawful to a lawful transaction would be lost under my proposal.

Yet, there is no particular reason to believe trust breeds legality. Lawyers likely lack the business sense to design alternative legal transactions that would appeal to crooked clients. If lawyers cannot design such transactions, there is no reason for a truly bad-actor client to listen to the lawyer, especially when the existing rule structure gives the client reason to believe the lawyer's self-interest will ultimately lead her to stay silent and close the deal. A credible threat of lawyer disclosure is a more likely deterrent in such a case.

More fundamentally, lawyers would likely be unable to salvage many otherwise fraudulent transactions even if crooked clients were willing to confide and follow the advice of their lawyers. In the archetypal fraud case, a client (issuer) wants to attract investors. Rational investors make decisions based on the economics of the client's business. How a lawyer puts a deal together may affect the economics of a client's business at the margin, but lawyers can only do so much. Lawyers cannot actually generate cash flows or raise the market price of assets, and it is unlikely that legal structuring will improve the economics of a transaction so much that a client who would otherwise have lied to get money could be persuaded to tell the truth. ${ }^{69}$ More likely, where a client is in bad financial shape, obeying the law (as by disclosing how bad things are) will mean foregoing the deal. Because clients who want money badly enough to defraud investors are likely to reject a lawyer's advice rather than foregoing the transaction, even a fully informed lawyer is unlikely to make the difference between a client's decision to follow the law and the decision to break it. ${ }^{70}$

The narrative in which the lawyer saves the day by persuading the client to do the right thing is something of an epic poem of professional responsibility. It is often invoked to caution against attempts to make rules encouraging or requiring lawyers to blow the whistle on clients. ${ }^{71}$ One can see how the narrative might appeal to lawyers who want to play the hero, but I am willing to bet that in the real world lawyers rarely do play the hero. ${ }^{72}$ If lawyers do any good in such cases, it is probably by dissuading

69. The inverse is true as well. A sound business that consummates an unlawful transaction is relatively unlikely to cause significant harm to investors precisely because the business is sound. It may make them less money than they would have made in a lawful transaction, but such an issuer is unlikely to cause the sort of investor devastation one sees in cases such as Enron.

70. This may mean that lawyers who suppose they have a chance to stecr the client straight, see supra text accompanying note 20 , are actually fooling themselves most of the time. Because either disclosure or withdrawal is costly to the lawyer, one can easily see how that thinking might occur.

71. See, e.g., U.S. Securities and Exchange Commission, supra note 60.

72. 1 limit this bet to fraudulent transactions. 1 am sure lawyers make the difference between lawful and unlawful structures all the time. Where the client is solvent, however, the reason for the difference in legality is that the client could close a lawful transaction even if it meant telling the truth 
clients from proceeding at all, which has the same effect as my trusteroding proposal. ${ }^{73}$

\section{Client Type Analysis Is Not Feasible}

The main objection to analysis that distinguishes between honest and dishonest clients is that such distinctions cannot be drawn in practice. A lawyer might not actually know until a deal closes whether a client is being honest or a crook. For example, a client and lawyer might disagree over disclosure, and the lawyer might think the client will give in and follow the law, only to find that the client ultimately refused and insisted on closing a tainted deal. This is a problem, but it is not much of an objection to my proposal. Under current law, the lawyer already has an ethical obligation not to help close a transaction she knows is fraudulent, and perhaps to withdraw from representing a client engaged in fraud ${ }^{74} \mathrm{Clients}$ who do not reveal their type until the last minute make $e x$ ante disclosure harder, but not impossible. Especially for last-minute reports, in which investors may have incurred costs they might sue to recover, my proposal makes ex ante disclosure less costly and thus more likely. The proposal certainly makes ex post disclosure more likely, and ex post disclosure is better than no disclosure. Under my proposal, a lawyer who honestly mistook the client's type and closed a transaction under pressure might be more likely to make early ex post disclosure than they are now. Early ex post disclosure might be particularly valuable to investors, who might, for example, sue quickly to establish a constructive trust over the invested funds.

\section{The Proposal Treats the Lawyer Like Any Other Professional}

Another objection to my proposal is that it treats lawyers the same as other professionals involved in a fraud, casting all parties as equivalent coconspirators. The proposal, one might argue, ignores the high ethical standards of the legal profession and lowers the status of lawyers to make them seem less professionally distinctive.

1 agree with this criticism. Though this brief Essay is not the place to engage the very large literature on "professionalism," in my view lawyers would be more ethical in the ordinary sense of that term if they think of themselves as ordinary persons doing a job rather than as "professionals." 1 suspect notions of professionalism create psychological distance between

about its business. Where the choice is fraud or nothing, however, 1 doubt that lawyers will save the day.

73. My bottom line on this point is that a lawyer's only real defense against bad actor clients is to avoid representing them in the first place. Client screening (and, if necessary, client firing) may be the single most important thing a lawyer does. No disclosure rule changes that, and neither does my proposal.

74. Model Rule 1.2(d) should prevent the lawyer from closing the transaction and Model Rule $1.16(a)$ requires the lawyer to withdraw. My proposal does not change these rules. 
lawyers and the real-world consequences -including harms-of their acts. I am against that. I would prefer that lawyers think of themselves as wellpaid workers plying a trade than as special persons entitled to special treatment.

One does not have to agree with my arguably jaded view of "professionalism" to support this proposal, however. One need only believe that lawyers take the personal costs of disclosure into account when deciding whether to disclose. Judicial decisions that adopt this premise are more persuasive than those that do not, ${ }^{75}$ and one need accept no more to endorse my proposal on at least an experimental basis. If it produces social benefits, we could weigh those against any losses an erosion of professional status might entail. If nothing changed, it is unlikely that the profession's status would go down very much.

One might also object that, even if removing lawyers as a source of compensation is unlikely to hurt investors, extending immunity to accountants and investment bankers would cause serious harm because they often have deeper pockets than lawyers and are generally more deeply involved in the fraud. Accountants, for example, certify financial statements, and investment bankers often make material representations. I am not sure that all accountants and bankers are more affluent than all lawyers, but they probably are more involved. Even taken as true, this premise gives lawyers an incentive to disclose first to avoid paymg for the liability share of a more culpable accountant or banker who beat the lawyer to the punch in cases of joint and several liability. That should help investors, who would rationally prefer to have the poorest, least responsible party blow the whistle on the others. It is true that bankers and accountants might want to jump first, because their liability might be greater. However, lawyers would know that and, by the standard prisoners' dilemma logic in which each player takes into account the incentives of other players, all parties would feel pressure to disclose.

A jurisdiction worried about this point could limit the immunity proposal to cover only lawyers. I would oppose such a limitation, however, on several grounds. First, reducing the number of players with an incentive to disclose would lessen the important trust-eroding effect of the proposal. Second, such a limitation would be another example of unduly singling out lawyers for special treatment. Third, the limitation might lead clients to conceal facts from lawyers and seek "legal" advice from accountants and bankers who would be more likely to cooperate with the fraud. Disclosures

75. Compare Gen. Dynamics Corp. v. Superior Court, 876 P.2d 487, 501 (Cal. 1994) (recognizing wrongful discharge claim for in-house counsel in part to counteract the "considerable economic and cultural pressures ... to silently conform" to workplace norms), with Balla v. Gambro, Inc., 584 N.E.2d 104 (Ill. 1991) (refusing to recognize such a claim on the ground that existing disciplinary rule created adequate incentive for disclosure). 
to such players would not be privileged in investor litigation, but an excessively optimistic client or one obsessed with near-term survival, for example, might not care. Then the fraud will occur and the lawyer might get caught in a financial meltdown without having the chance to structure a different deal.

Fourth, limiting immunity to lawyers might also create a moral hazard risk that my proposal reduces. If a lawyer could gain (in fees and reputation) from unlawful deals that seemed likely to succeed, while bailing out of deals that seemed likely either to fall through or to be detected within the relevant limitations period, ${ }^{76}$ the lawyer might have an incentive to give excessively aggressive advice or even actively promote fraudulent schemes. ${ }^{77}$ However, if lawyers cannot trust other professionals to go along with the scheme, and might be left paying the liability share of some other (disclosing) participant, then this strategy is very risky and thus not likely to appeal to a rational lawyer. Giving each participant the incentive to blow the whistle on the others is important to the trust-eroding logic of my proposal, and lawyer-only immunity is therefore undesirable.

\section{E. Why Not Try Mandatory Disclosure?}

Lastly, one might object that if my premises are correct, disclosure should be mandatory for lawyers, similar to the requirement the SEC has considered establishing in its rules implementing section 307 of the Sarbanes-Oxley Act. ${ }^{78}$ My proposal could complement a mandatory disclosure regime, so this is not actually an objection. If the SEC adopts a mandatory whistle-blowing regime, they should at least consider combining it with a policy such as the one I propose. Sticks are useful, but carrots are useful, too.

\section{CONCLUSION}

Most lawyers are undoubtedly honest and will try to do the right thing most of the time. Lawyers are human, however, and doing the right thing gets harder as it gets more expensive. Disciplinary rules that permit disclosure, such as the 2003 amendments to Model Rules I.6 and I.13, are welcome, but they are unlikely to change actual practice significantly becausc they do not take into account the costs of disclosure. If the legal profession

76. My thanks to Professor Stephen Bundy for emphasizing this point. Professor Cohen makes a related point. Cohen, supra note 10, at 295.

77. Model Rule 1.2(d) forbids lawyers from assisting clients in fraudulent conduct. Where a fraud is likely to succeed, however, the expected cost of discipline may be quite low because the fraud is not likely to be discovered, so the moral hazard problem mentioned in the text could remain even with the formal prohibition.

78. Koniak, When the Hurlyburly's Done: The Bar's Struggle with the SEC, supra note 3, at 1269-75 (discussing the evolution of the SEC's implementing rules). 
is serious about lawyers blowing the whistle on client financial misconduct, it should adopt rules that take those costs into account.

My proposal suggests one way to address these costs. While it is unlikely to become law any time soon, I hope it will serve as a template for a serious discussion about the economics of these issues. Trust can be bad, and we can gain useful insights into how to curb fraudulent lawyering by modeling lawyers as conspirators whose trustworthiness sometimes causes harm. At a minimum, we can do better than to adopt permissive rules that everyone knows are not likely to be used. A practical problem requires a practical solution, such as the one I offer here. 